\title{
Nilai-Nilai Kepemimpinan dan Pendidikan Karakter: Studi Tokoh Bupati Sumoroto III Raden Mas Brotodirjo
}

\author{
Safira Anugeraheni, S Soebijantoro* \\ Universitas PGRI Madiun \\ *Corresponding author`s e-mail: soebijantoro@unipma.ac.id
}

\begin{abstract}
This study aims to examine the leadership values of the Sumoroto III Regent, Raden Mas Brotodirjo, as an effort to form character education in schools. The research method used is descriptive qualitative. Data collection was carried out through observation, interviews, and study documentation. Observations were made by direct observation non-participation in various community activities. Interviews were conducted either in a structured manner or independently. The data analysis of this study was guided by the steps of qualitative research data analysis, namely: data reduction, data presentation, and drawing conclusions. From the results of data analysis, it was concluded that the leadership values of Raden Mas Brotodirjo in leading the Sumoroto district included integrity and morality as well as the ability to see the vision and mission of the state. While the value of character education contained in the leadership of Raden Mas Brotodirjo, namely a) Love the Motherland, b) National Spirit and c) Responsibility.
\end{abstract}

Keywords: Leadership, Character, Raden Mas Brotodirjo

Abstrak: Penelitian ini bertujuan untuk mengkaji nilai nilai kepemimpinan Bupati Sumoroto III yaitu Raden Mas Brotodirjo sebagai upaya pembentukan Pendidikan karakter di sekolah. Metode penelitian yang digunakan adalah deskriptif kualitatif. Pengumpulan data dilakukan melalui observasi, wawancara, dan studidokumentasi. Observasi dilakukan dengan pengamatan langsung secara non partisipasi dalam berbagai kegiatan masyarakat. Wawancara dilakukan baik secara terstruktur maupun secara bebas...Analisis data penelitian ini berpedoman pada langkah-langkah analisis data penelitian kualitatif yaitu: reduksi data, penyajian data, dan penarikan simpulan. Dari hasil analisis data diperoleh kesimpulan bahwa nilai kepemimpinan Raden Mas Brotodirjo dalam memimpin kabupaten Sumoroto antara lain integritas dan moralitas serta kemampuan dalam melihat visi dan misi kenegaraan. Sedangkan nilai Pendidikan karakter yang terkandung dalam kepemimpinan Raden Mas Brotodirjo yaitu a) Cinta Tanah Air, b)Semangat kebangsaan dan c) Bertanggung Jawab.

Kata kunci: Kepemimpinan, Karakter, Raden Mas Brotodirjo

\section{Pendahuluan}

Pendidikan karakter merupakan gerakan nasional yang menciptakan sekolah yang membina generasi muda yang beretika, bertanggung jawab, dan peduli dengan mencontoh dan mengajarkan karakter yang baik melalui penekanan pada nilai-nilai universal yang kita semua miliki (Aynur Pala, 2011). Dalam konteks tersebut dijelaskan bahwa karakter yang baik tidak terbentuk secara otomatis; itu dikembangkan dari waktu ke waktu melalui proses pengajaran, teladan, pembelajaran dan praktek yang berkelanjutan. Ini dikembangkan melalui pendidikan karakter. Pengajaran karakter baik yang disengaja sangat penting dalam masyarakat saat ini karena generasi muda akan menghadapi banyak tantangan yang tidak diketahui oleh generasi sebelumnya. Salah satu problem besar dalam dunia Pendidikan di Indonesia adalah lunturnya akhlak dan moral peserta didik yang mulai mengikis karena 
adanya perubahan hidup, gaya hidup urban, yang menyebabkan perubahan kehidupan generasi muda (Tilaar, 2004). Salah satu parameter terkikisnya akhlak dan moral generasi muda dalam beberapa kasus antara lain keterlibatan generasi muda dalam tindak kriminal penggunaan narkoba, hingga tindak pidana pencurian dengan kekerasan sepertipembunuhan yang melibatkan remaja (Mulyasa dalam Binti Maunah, 2015) berpendapat bahwa fenomena tersebut dalam kehidupan sosial kemasyarakatan khususnya bagi generasi muda kurang baik sehingga memerlukan peningkatan kualitas moral melalui peran pendidikanmengingat melalui pendidikanlah kualitas hidup manusia dapat diperoleh melalui sebuah proses perubahan tingkah laku menuju kehidupan yang baik bahkan untuk mencapai pengetahuan dan pengalaman yang tinggi.

Salah satu elemen penting dalam dunia Pendidikan untuk mewujudkannya adalah melalui pendidikan formal yaitu melalui sekolah. Saat ini pendidikan di Indonesia sedang menggalakkan pendidikan karakter dimana seperti dimuat dalam undang-undang nomer 20 tahun 2003 mengenai Sistem Pendidikan Nasional disebutkan bahwa pendidikan nasional berfungsi untuk merubah watak serta karakter anak bangsa menjadi lebih bermatabat dan memiliki sikap sesuai dengan Pancasila serta bertujuan untuk menciptakan generasi muda yang tat terhadap Tuhan Yang Maha Esa dan mampu mengenali ptensi diri serta bertanggung jawab atas segala kewajibannya (Adelina Hasyim, 2015). Persoalan dalam konteks tersebut diatas sesungguhnya merupakan persoalan multidimensi dan sudah lama menjadi keprihatinan demi keprihatinan dan sering diungkapkan oleh berbagai elemen masyarakat yang masih berharap bahwa krisis multidimensi ini segera berakhir. Menurut Sartono Kartodirjo (dalam Soebijantoro, 2011) disebutkan bahwa terdapat sejumlah persoalan besar sedang dihadapi oleh bangsa Indonesia.

Persoalan tersebut berkisar pada masalah prasangka religius, sentimen antaretnik, eksklusivisme, sektarianisme, dan komunalisme yang bermuara pada transformasi struktura lmasyarakat Indonesia dalam segala dimensinya. Masalah-masalah tersebu tmuncul terkait dengan kemajemukan masyarakat Indonesia. Sehingga masyarakat Indonesia dihadapkan pada kebutuhan yang mendesak untuk merekonstruksi kembali kebudayaan nasional yang dapat menjadi kekuatan penyatu mengikat seluruh keragaman. Apresiasi akan hal itu disebabkan karena fakta historis menunjukkan bahwa bangsa Indonesia telah menunjukkan kemampuan beradaptasi dan menerima budaya-budaya besar sehingga dapat memperkecil perbedaan-perbedaan tersebut. Dalam konteks tersebut menurut Suhartono (dalam Soebijantoro, 2011) dijelaskan bahwa salah satu entry point untuk mengurai carut marut problem bangsa ini yang mengarah pada perilaku negatif yang menurunkan pamor pemerintah karena bangsa ini telah kehilangan banyak karakter positif. Hal ini bisa terjadi 
sebab sesungguhnya karakter tidak lain adalah pegangan dalam berperilaku (positif) dalam masyarakat yang karena berbagai hal telah tereduksi. Oleh karena pendidikan karakter berkenaan dengan keseluruhan performance seseorang dalam berinteraksi dengan lingkungan, sehingga di dalam karakter ini terkandung unsur moral, sikap sampai perilaku. Secara substantive,pendidikan karakter berkaitan dengan pendidikan afektif. Aspek afektif menurut Graham merupakan aspek yang berkaitan dengan apa yang terdapat dalam diri peserta didik (the internal side)sehingga keberadaannya selalu tersembunyi sebab ini berkenaan dengan dunia kejiwaan, cita-cita, dan rasa (Masrukhi, 2011). Oleh karena itu dalam proses belajar mengajar pada pendidikan formal, diperlukan kemampuan guru dalam mendekatkan materi pembelajaran dengan siswa melalui ketersediaan sumber belajar yang dapat merangsang munculnya minat serta bakat bahkan cita-cita.

Salah satu upaya penanaman pendidikan karakter di sekolah adalah melalui pembelajaran sejarah di kelas. Dengan adanya penanaman nilai karakter melalui pembelajaran sejarah, peserta didik akan mampu mengambil pengalaman hidup dari peristiwa masa lampau. Salah satu materi dalam pengajaran di sekolah adalah mengkaji tipe kepemimpinan seorang tokoh. Ebrahim Hasan Al Khajeh (2018) menjelaskan bahwa Kepemimpinan adalah salah satu penentuutama yang terkait dengan keberhasilan dan kegagalan organisasi mana pun. Artinya bahwa tipe kepemimpinan adalah cara orang diarahkan dan dimotivasi oleh seorang pemimpin untuk mencapai tujuan organisasi. Dalam konteks inilah seorang pendidik termasuk guru harus mampu menanamkan nilai-nilai pendidikan karakter melalui berbagai tokoh sejarah yang untuk membentuk karakter anak bangsa yang lebih baik lagi dan sejalan dengan tujuan pendidikan di Indonesia melalui ketersediaan sumber belajar sejarah melalui eksplorasi tentang tokoh dalam sejarah lokal yang dapat dipergunakan sebagai bahan kajian bagi guru maupun tenaga pendidik dalam ikut serta membangun karakter bangsa.

Salah satu diantaranya rekam jejak Bupati Somroto III yaitu Raden Mas Brotodirjo yang merupakan tokoh penting dalam sejarah kabupaten Somoroto khususnya pada masa penjajahan kolonial Belanda. Satu hal yang menarik ditengah upaya politik represif Kolonial dalam campur tangan elit lokal, Raden Mas Brotodirjo berani menunjukkan sikap berseberangan dan non kooperatif terhadap segala kebijakan colonial Belanda khususnya di Ponorogo. Sikap inilah yang menarik bagi peneliti untuk mencoba mengkaji rekam jejak perjuangannya d alam konteks kepemimpinan serta nilai pendidikan karakter baik dalam mempimpin kabupaten Sumoroto maupun perjuangan dalam menghadapi kolonial Belanda yang dapat diimplementasikan melalui pengajaran sejarah di sekolah. Dalam konteks 
pengembangan penelitian sejarah khususnya sejarah local, maka kajian ini diharapkan pula dapat mendiskripsikan peran elite lokal dalam perjalanan Sejarah Nasional Indonesia.

\section{Metode}

Penelitian ini adalah penelitian deskriptif kualitatif. Pengumpulan data dilakukan melalui observasi, wawancara dan studi dokumentasi. Observasi dilakukan dengan pengamatan langsung secara non partisipasi dalam berbagai kegiatan. Wawancara dilakukan baik secara terstruktur dengan daftar pertanyaan yang telah disistematisasikan berdasarkan gambaran awal yang didapat ataupun secara bebas dengan melakukan diskusi (FGD) yang terkait dengan obyek yang diteliti. Nara sumber penelitian ini adalah perangkat Desa, juru pelihara, guru sejarah serta praktisi peneliti sejarah. Pemilihan Nara sumber dilakukan secara selektif berdasarkan kebutuhan data. Selain mengumpulkan data primer, juga mengumpulkan data sekunder. Data tersebut adalah profil Kabupaten Ponorogo yang meliputi, data-data wilayah secara umum, dan data mengenai kesejarahan Kabupaten Ponorogo dari sumber buku dan literature lain, serta penelusuran berbagai informasi yang dipublikasikan dalam media elektronik maupun cetak. Peneliti juga mengumpulkan data yang bersifat visual dalam bentukfoto dan video.

Analisis data penelitian ini berpedoman pada langkah-langkah analisis data penelitian kualitatif yang dikemukakan oleh Moleong (2011), yaitu: (1) reduksi data, (2) penyajian data dan (3) penarikan simpulan. Reduksi data meliputi proses pemilihan, pemfokusan, penyederhanaan, pengabstraksian, pentransformasian data, dan pengategorian untuk memudahkan pengorganisasian data. Dari proses itu, penyajian data dilakukan untuk disusun secara sistematisd engan memperlihatkan kaitan alur data dan menggambarkan apa yang sebenarnya terjadi sehingga memudahkan peneliti untuk menarik simpulan. Penarikan simpulan dilakukans ejak tahap pengumpulan data dengan cara mencatat dan memaknai fenomena yang menunjukkan keteraturan, kondisi yang berulang-ulang, sertapola-polaatau model yang dominan tahapan analisis yaitu reduksi data, penyajian data dan penarikan kesimpulan.

\section{Hasil Dan Pembahasan}

\section{A. Masa Pemerintahan Raden Mas Brotodirjo Bupati Somoroto III}

Kabupaten Somoroto didirikan oleh Raden Mas Tumenggung Prawiradirja pada tahun 1805, beliau adalah keturunan ke-13 dari Raja Majapahit Brawijaya V. Raden Mas Brotodirjo memegang tampuk Bupati Sumoroto menggantikan ayahnya Raden Mas Tumenggung Sumonagoro. Semasa pemerintahan Mas Tumenggung Sumonagoro kondisi social politik di Somoroto saat itu bersamaan dengan Perang Diponegoro (1825-1830) dan 
pelaksanaa Tanam Paksa (1830-1870). Kebijakan Cultuur stelsel oleh Gubernur Jenderal Van den Bosch lebih berorientasi kepentingan ekonomi melalui keberadaan para tokoh elit local. Tidak terkecuali Raden Masa Brotodirjo II. Sepeninggal Raden Mas Brotodirjo II, kepemimpinan di Sumoroto berlanjut pada putranya Raden Mas Brotodirjo III. Pada masa kepemimpinannya daerah Ponorogo diwajibkan pula untuk menanam kopi dan tom (bahan untuk membuat batik atau tekstil). Oleh karena kebijakan colonial yang tidak sejalan dengan pemikiran raden Mas Brotodirjo III, maka dengan rasa tanggung jawab dan keberanian, beliau selalu tegas menolak semua kebijakan pemerintah kolonial apabila ada terindikasi tidak berpihak pada kesejahteraan rakyatnya. Semasa kepemimpinannya, hambatan yang dialami adalah kecenderungan pemerintah Kolonial Belanda yang ingin memaksakan keinginan melalui pimpinan elit lokal. Pelaksanaan Taman Paksa pada umumnya diserahkan sepenuhnya kepada bupati masing-masing.

Selain itu untuk mensukseskan pelaksanaan Tanam Paksa, Pemerintah Belanda memberi imbalan hadiah atau prosentase kepada kepada para bupati yang bisa mengumpulkan hasil pertanian melebihi ketentuan yang ditetapkan oleh Pemerintah Belanda. Dengan demikian tidak mengherankan sering dijumpai bupati yang berlombalomba untuk mendapatkan hadiah dengan cara memaksa rakyatnya untuk bekerja melebihi kemampuannya. Raden Mas Brotodirjo sangat peduli dengan rakyatnya sehingga menolak kebijakan tersebut karena jika rakyat Somoroto dipaksa untuk menanam kopi dengan alasan apabila kebijakan itu dilakukan maka akan terjadi adalah bencana kelaparan karena Kopi bukan makanan pokok yang dapat memenuhi kehidupan rakyat Somoroto, tetapi sematamata untuk memenuhi kepentingan colonial. Kegigihan Raden Mas Brotodirjo III tersebut membuahkan hasil dimana rakyat Somoroto tidak diperintah untuk menanam kopi dan tom, tetapi rakyatnya diperintah untuk tetap menanam padi.

Selain penolakan Tanam Paksa, tepatnya pada tahun 1837 atas campur tangan pemerintah Belanda dengan alasan untuk memudahkan pengawasan terhadap daerah Ponorogo dan sekitarnya, Pemerintah Belanda berkeinginan untuk menggabungkan empat kabupaten yang ada di Ponorogo menjadi satu. Keinginan pemerintah kolonuial Belanda tersebut ditentang oleh Bupati Somoroto Raden Mas Brotodirjo dengan mengatakan bahwa jika Kabupaten Somoroto dihapus dan digabung menjadi satu kabupaten dengan ketiga kabupaten lainnya, kami tidak bertanggung jawab jika terjadi kerusuhan dimana-mana. Keputusan tersebut di atas juga menunjukkan betapa Raden Mas Brotodirjo sangat mementingkan rakyatnya karena sadar bahwa jika Kabupaten Somoroto bergabung dengan Kabupaten lainnya Belanda akan lebih mudah melakukan tidakan sewenang-enang terhadap masyarakat Kabupaten Somoroto. Meskipun menolak untuk bergabung dengan kabupaten 
lain, Raden Mas Brotodirjo tetap menghargai keputusan kabupaten lain yang bergabung menjadi satu dengan cara Kabupaten Somoroto tetap berdiri berdampingan dengan Kabupaten Ponorogo Kota Tengah yang merupakan gabungan dari Kabupaten Ponorogo Kutho Wetan, Kabupaten Pedanten dan Kabupaten Polorejo Raden Mertohadinegoro sebagai bupati pertama.

\section{B. Nilai Kepemimpinan dan pendidikan karakter Raden Mas Brotodirjo}

Seseorang ditetapkan menjadi pemimpin akan menanggung beban tanggung jawab baik secara fisik maupun spiritual terhadap keberhasilan aktivitas kerja dari yang dipimpin, sehingga menjadi pemimpin itu tidak mudah dan tidak akan setiap orang mempunyai kesamaan di dalam menjalankan ke-pemimpinannya artinya kepemimpinan hanya dapat dilaksanakan oleh seorang pemimpin dan seorang pemimpin adalah seseorang yang mempunyai keahlian memimpin, mempunyai kemampuan mempengaruhi pendirian/pendapat orang atau sekelompok orang tanpa menanyakan alasan-alasannya. Seorang pemimpin adalah seseorang yang aktif membuat rencana-rencana, mengkoordinasi, melakukan percobaan dan memimpin pekerjaan untuk mencapai tujuan bersama-sama. Terkait dengan hal itu, James C. Sarros (2006) mengatakan bahwa seorang pemimpin akan dikenal apabila yang bersangkutan dapat menunjukkan konsistensi dan integritas terhadap nilai-nilai etika kehidupan seperti kepercayaan diri , optimisme, mampu memberi harapan, kepada orang lain. Dijelaskan pula oleh James C. Sarros bahwa kepemimpinan seseorang dapat memberikan nilai kepada kita bagaimana terdapat karakter yang dapat membangun lingkungan yang kompetitif dan suportif untuk bekerja. Termasuk integritas seorang pemimpin dalam menyelaraskan antara perbuatan dan ucapan maupun kemampuan koginitif dalam menguasai ilmu pengetahuan (2006).

Dengan demikian kemampuan seseorang dalam memimpin sebuah organisasi sangat diharapkan pada konteks tatanan sosial, moral, ekonomi dan politik masyarakat. Figur seorang pemimpin bisa menjadi inspirasi bagi orang lain untuk mengambil banyak pelajaran,. Salah satu diantaranya adalah memahami nilai nilai kepemimpinan. Nilai-nilai kepemimpinan adalah sejumlah sifat-sifat utama yang harus dimiliki seorang pemimpin agar kepemimpinannya dapat efektif dan efisien untuk mencapai tujuan yang telah ditentukan. Artinya sifat-sifat utama tersebut merupakan jiwa yang dapat membuat seseorang mampu menjalankan kepemimpinannya dengan berhasil guna. Beberapa nilai kepemimpinan yang perlu dimiliki seorang pemimpin antara lain adalah antara lain nilai kepemimpinan yang perlu dimiliki seorang pemimpin antara lain 1) Integritas dan moralitas. Integritas berkenaan dengan mutu, sifat serta kondisi yang menunjukkan kesatuan yang utuh sehingga memiliki potensi dan kemampuan yang memancarkan kewibawaan dan kejujuran. Sedangkan 
Moralitas menyangkut ahlak, budi pekerti, susila, ajaran tentang baik dan buruk, segala sesuatu yang berhubungan dengan etiket, adat sopan santun. Persyaratan integritas dan moralitas penting untuk menjamin kepemerintahan yang baik, bersih dan berwibawa, 2) Tanggung jawab. Artinya seorang pemimpin harus memikul tanggung jawab dalam melaksanakan visi, misi dan mandat yang dipercayakan kepadanya, 3) Visi Seorang Pemimpin. Artinya kemana arah dan tujuan organisasi dan orang-orang yang dipimpin akan dibawa. mana kapal dengan penumpangnya akan di arahkan, 4) Kebijaksanaan (wisdom). Artinya kearifan seorang pemimpin dalam memutuskan sesuatu sehingga keputusannya adil dan bijaksana. Hal ini sangat penting sebab kebijaksanaan sering diidentikkan dengan makna yang lebih dari sekedar kepandaian. Nilai nilai kepemimpinan tersebut sangat berpengaruh terhadap upaya untuk membangun dan menumbuhkan Pendidikan karakter dalam segala manifestasinya terutama dalam dunia Pendidikan.

Seperti yang dijelaskan oleh James Sarros terebut diatas bahwa karakter yang baik akan tebentuk melalui proses dalam praktek Pendidikan yang berkelanjutan. Sekolah memainkan peran untuk melanjutkan peran proaktif dalam membantu keluarga dan masyarakat dengan mengembangkan lingkungan yang penuh perhatian di mana siswa mempelajari nilai-nilai etika bermasyarakat. untuk mendukung nilai-nilai yang diajarkan di kelas (Character Education Partnership). Kemendiknas telah menetapkan 18 nilai karakter yaitu religius, jujur, toleransi, disiplin, kerja keras, kreatif, mandiri, demokratis, rasa ingin tahu, semangat kebangsaan, cinta tanah air, menghargai prestasi, bersahabat/komuniktif, cinta damai, gemar membaca, peduli lingkungan, peduli sosial, dan tanggung-jawab. Berdasarkan 18 nillai tersebut, ada 3 nilai pendidikan yang sesuai dengan karakter Raden Mas Brotodirjo yaitu bertanggungjawab, semangat kebangsaan yang tinggi dan cinta tanah air. Karakter tersebut dapat menjadi teladan bagi generasi muda untuk bertanggung jawab dalam berbagai hal, semangat kebangsaan dengan peduli pada permasalahan bangsa dan negara, dan mencintai produk dalam negeri.

1. Cinta Tanah air

Cinta tanah air yaitu sikap dan perilaku yang menunjukkan rasa memiliki, bangga, setia, selalu ada untuk negara, peduli, dan penghargaan yang tinggi terhadap bahasa, budaya, ekomoni, politik, dan sebagainya, sehingga tidak mudah menerima tawaran bangsa lain yang dapat merugikan bangsa sendiri. (Edmu Yulfizar, 2018). Sikap kenegarawanan dari Raden Mas Brotodirjo ditunjukkan dengan sikap, anti penjajahan, dan tidak mau dilecehkan bangsa lain, mendahulukan kepentingan bangsa dan negara, berbuat untuk kepentingan bangsa serta memiliki ideologi kebangsaan yang kuat. Hal ini ditunjukkan dengan sikap Raden Mas Brotodirjo yang secara berani dan tegas menentang 
Belanda. Karakter cinta tanah air yang dimiliki oleh Raden Mas Brotodirjo ini bisa dijadikan pedoman atau contoh bagi generasi penerus bangsa. Generasi penerus bangsa harus memiliki karakter tanah air dengan memiliki karakter cinta tanah air, mereka akan berusaha dengan segala daya upaya yang dimilikinya untuk melindungi, menjaga kedaulatan, kehormatan dan segala apa yang dimiliki oleh negaranya. Rasa cinta tanah air inilah yang mendorong perilaku individu untuk membangun negaranya dengan penuh dedikasi. Oleh karena itu, karakter cinta tanah air perlu ditanamkan dalam jiwa setiap penerus bangsa yang menjadi warga dari sebuah negara atau bangsa agar tujuan hidup bersama dapat tercapai.

2. Semangat kebangsaan

Semangat kebangsaan yaitu sikap yang menjujung tinggi atau mementingkan negara dibanding kepentingan pribadi maupun kelompok sehingga selalu siap apabila negara membutuhkan. (Edmu Yulfizar, 2018). Sikap ini dimiliki oleh Raden Mas Brotodirjo karena bersedia dengan ikhlas memberikan waktu, tenaga, pikiran, hingga harta untuk kepentingan orang lain dalam hal kebaikan. Pengorbanan tentunya akan merugikan bagi yang melakukan, namun, rasa ikhlas, kepercayaan, dan semangat membuat kerugian tersebut menjadi keuntungan yang lebih besar. Semangat kebangsaan harus dimiliki generasi muda karena dengan adanya semangat kebangsaan yang tinggi dapat meningkatkan rasa cinta antar sesama sehingga tercipta kehidupan yang damai tanpa ada pertikaian dan juga konflik yang dapat memecah belah semangat persaudaraan. Selain itu dapat menumbuhkan sikap peduli terhadap sesama yang sedang membutuhkan.

3. Tanggung jawab

Tanggung jawab yakni sikap dan perilaku seseorang yang bersungguh-sungguh dan menyelesaikannya sampai akhir berbagai tugas dan kewajibannya, baik yang berkaitan dengan diri sendiri, sosial, masyarakat, bangsa, negara, maupun agama (Edmu Yulfizar 2018). Karakter ini ditunjukkan dengan Raden Mas Brotodirjo yang mampu memimpin Kabupaten Somoroto dengan baik dan selalu berusaha untuk membela, melindungi dan berusahamensejahterakan rakyatnya. Karakter bertanggung jawab sangat penting bagi kehidupan karena dalam melakukan berbagai hal tanggung jawab merupakan dasar untuk mencapai sesuatu secara maksimal. Untuk generasi muda tentunya sikap tanggung jawab sangat penting karena banyak kewajiban yang harus diselesaikan baik itu kewajiban terhadap diri sendiri, negara, dan masyarakat sekitar jika dalam melakukan kewajiban selalu bersungguh-sungguh dan penuh tanggung jawab maka kesuksesan akan diraih. Meski tipe kemimpinan Raden Mas Brotodirjo cenderung bersifat paternalistik, 
namun sebagai seorang pemimpin sekaligus elit lokal, menunjukkan nilai kepemimpinan yang dapat dipergunakan untuk membangun spirit Pendidikan karakter bagi generasi muda. Nilai nilai tersebut antara lain: 1) Integritas dan moralitas. Sebagai seorang pemimpin, Raden Mas Brotodirjo merupakan salah satu elit local di Nusantara yang berseberangan dengan kebijakan kolonial Belanda. Kebijakan kolonial yang cenderung menjadikan bangsa Indonesia sebagai obyek ekploitasi mendorong Raden Mas Brotodirjo menolak kebijakan cultuurstelsel. 2) Visi Seorang Pemimpin. Hal ini dapat ditunjukan ketika pada masa pemerintahan Raden Mas Brotodirjo (Bupati Somoroto III) pada tahun 1837 yang menolak atas campur tangan pemerintah Belanda dengan alasan untuk memudahkan pengawasan terhadap daerah Ponorogo dan sekitarnya, Dalam pemahaman RM Brotodirjo, strategi kolonial Belanda ini merupakan siasat untuk mewujudkan politik adu domba.

\section{Kesimpulan}

Dari penjelasan tersebut diatas, maka dapat disimpulkan bahwa sebagai elite lokal Jawa dengan tipe kepimpinan patrialistik, terdapat nilai kepemimpinan yang dapat dipergunakan untuk membangun pendidikan karakter bagi generasi muda antara lain integritas dan moralitas serta kemampuan dalam melihat visi dan misi kenegaraan. Adapun nilai Pendidikan karakter yang terkandung dalam kepemimpinan RM Brotodirjo III adalah a) Cinta Tanah Air, b)Semangat kebangsaan dan c) Bertanggung Jawab.

\section{Daftar Pustaka}

Angito albi \& Setiawan Johan. (2018). Metodologi Penelitian Kualitatif. Sukabumi: CV Jejak. Aynur Pala. (2011). The Need For Character Education. International Journal of Social Sciences and Humanity Studies.Vol 3, No 2, 2011 ISSN: 1309-8063

Azizah, Nur. (2015). Penanaman Nilai - Nilai Pendidikan Karakter Dalam Pembelajaran Pendidikan Agama Islam Di Sma Negeri 1 Weleri Kendal Tahun Pelajaran 2015/2016. Skripsi Universitas Islam Negeri Walisongo Semarang.

Dwiwibawa, Rudy F \& Riyanto, Theo. (2008). Siap jadi pemimpin. Yogyakarta: Kanisius.

Ebrahim Hasan Al Khajeh. (2018). Impact of Leadership Styles on Organizational Performance.Journal of Human Resources Management Research Vol. 2018 (2018), Article ID 687849, DOI: 10.5171/2018.

Hanif, Muhammad (2016). Kesenian Dongkrek (Studi Nilai Budaya dan Potensinya sebagai Sumber Pendidikan Karakter). Gulawentah: Jurnal Studi Sosial 1 (2).

Hasyim, Adelina. (2015). Pembelajaran Ilmu Pengetahuan Sosial Berbasis Pendidikan Karakter. Yogyakarta: Media Akademi.

Kuswantoro, Agung. (2015). Pendidikan Karakter Melalui Publik Speaking. Yoogyakarta: Graha Ilmu.

Makinuddin \& sasongko H.T .(2006). Analisis Sosial : Beraksi Dalam Advokasi Irigasi. Bandung: Yayasan AKATIGA.

Mamik .(2015). Metodologi Kualitatif. Sidoarjo: Zifatama Publisher. 
Maunah, Binti. (2015). Implementasi Pendidikan Karakter Dalam Pembentukan Kepribadian Holistik Siswa. Jurnal Pendidikan Karakter: IAIN Tulungagung.

Purwowijoyo. (1985). Babad Ponorogo. Dinas Pariwisata dan Seni Budaya Kabupaten Ponorogo.

Rahmat, Saepul P. (2009). Penelitian Kualitatif. EQUILIBRIUM.

Sarros, C. James. (2006). Building character: A leadership essential. Journal of Business and Psychology . DOI: https://www.researchgate.net/

Soebijantoro. (2011). PembelajaranIlmuPengetahuan Sosial dan Pendidikan Karakter di Sekolah Dasar. Madiun :Jurnal Premier Educandum.

Sukiyat. (2020). Strategi Implementasi Pendidikan Karakter. Surabaya :CV Jakad Media Publishing.

Suparjan, Edy. (2019). Pendidikan Sejarah Untuk Membentuk Karakter Bangsa. Sleman: Depublish Publisher.

Tilaar, H.A.R. (1998). Beberapa Agenda Revormasi Pendidikan Nasinal Dalam Perspektif Abad 21. Magelang: Tera Indonesia.

Tilaar, H.A.R. (2004). Multikulturalisme tantangan-tantangan global masa depan dalam transformsi pendidikan nasional, Jakarta: Grasindo, 2004.

Wijaya, Hengki. (2018). Analisis Data Kualitatif Ilmu Pendidikan Teknolgi. Sulawesi Selatan: Sekolah Tinggi Theologi Jaffray. 